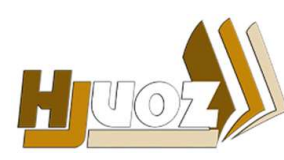

hjuoz.uoz.edu.krd p-ISSN: $2410-7557$ e-ISSN: $2518-5128$
كَّوارا زانستيّن مروّقايهتى يا زانكوّيا زاخوّ

مجلة العلوم الانسانية لجامعة زاخو

Humanities Journal of University of Zakho (HJUOZ)

Vol. 6, No. 1, Part 2, pp. 344-357, Mar.-2018

\title{
دور الحوافز في تحقيق الرضا الوظيفي للموظفين في جامعة زاخو \\ "دراسة استطلاعية"
}

\author{
خيرى على اوسو 1"و اثان يوسف حجى 2 جيا عصمت دينو2 \\ الكلية التقية الادارية، جامعة بوليتكنيك دهوك، أقليم كوردستان - العراق.

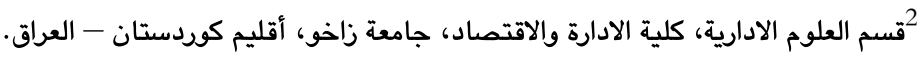

https://doi.org/10.26436/2018.6.1.597 2018/03 2017/03 تاريخ الاستلام: 2018/ تاريخ النشر:

الملخص:

يهدف البحث الى دراسة دود الحوافز في تحقيق الرضا الوظيفي للموظفين في جامعة زاخو، منطلقاً من مخطط فرضي ياخذ بنظر الاعتبار

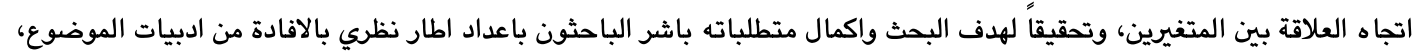
واعتمد البحث المنهج الوصفي التحليلي،وتم استخدام الاستبانة لاستطلاع اراء عينة البحث،والمكونة من الموظفين الذين بلغ عددهم

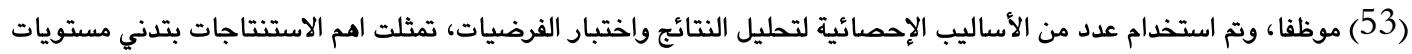
رضا الموظفين في الجامعة عن الرواتب والاجور الممنوحة لهم،وكذلك ضعف او محدودية وجود عدالة في توزيع العمل بين الموظفين في الأقسام العلمية للجامعة، وتوصل البحث الى مجموعة من المقترحات تمثلت اهمها بضرورة تحقيق الرضا للموظفين وخاصة فيما يتعلق بالرواتب والاجور الممنوحة لهم ،وكذلك تحقيق العدالة في توزيع العمل بين الموظفين في الأقسام العلمية للجامعة.

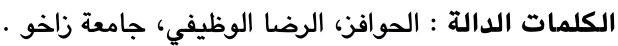

يعد التحفيز بنوعيها المادي والمعنوي من الامور المهمة لتحقيق رضا الموظفين، والتأثير في أدائهم وانتاجيتهم، ومن ثم تدقيق النجاح للمنظمة، أن الموظفين الذين يمنح لهم حوافز على العمل الوظيفي تكون لديهم قابلية العمل بجهد أكثر من غيرهم الى جانب اصرارهم الكبير في مواجهة الصعويات التي تصادفهم،كما أنهم يتمتعون بحماس عال تِاه

عملهم لتحفيز أهدافهم الوظيفية من اجل تحسين أدائهم الوظيفي. من هذا المنطلق فان البحث جاء ليعالج السؤال الرئيسي الاتي : ما مو دود الحوافز في تحقيق الرضا الوظيفي من وجهة نظر الموظفين

في جامعة زاخو؟

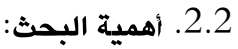

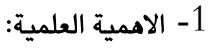

تنبع من أهمية ودود الحوافز في تحقيق الرضا الوظيفي لدى الموظفين في جامعة زاخو، ويساعد البحث على معرفة مدى توافر نظام حوافز فعّال يتناسب مع احتياجات الموظفين في الجامعة، ويما يتماشى مع الرؤية المستقبلية للجامعة، ويسهم في تحقيق رؤيتها وأهدافها

الاستراتيجية.

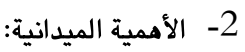

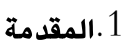

يعد الموظفين في الجامعة من مختلف التخصصات الدعامة الاساسية التي تستند إليها الجامعة الحديثة للوصول الى أهدافها فهم مصدر الفكر والعلم والمعرفة والتطوير وهم القادرين على تشغيل وتوظيف الموارد، لذا فان الادارة الحديثة تعمل على توفير نوعية متميزة من الموظفين والحرص على تدريبهم واكسابهم المهارات لعلاقتهم بالإنتاج والإنتاجية، ومن المعروف أن تصسين اداء الموظف وعطائه يعتمد بشكل كبير على الحوافز التي تدفع سلوكه في الإتجاه الذي يحقق أهداف الجامعة، كما ان الحوافزتوقظ الحماس والدافعية والرغبة في العمل للموظف، وتدفعهم للعمل بكامل طاقتهم وقوامم العقلية والجسدية، وأنها تعمل على منع شعور الفرد بالإحباط وتدفع العامل إلى المثابرة في عمله وتجعل كفاءته عالية. واتساقاً مع ما تقدم ولأهمية موضوع الحوافز والرضا الوظيفي فقد وجدنا من المناسب دراسة هذين المتغيرين وفق المحاود الآتية: 2.المحور الأول منهجية البحث 1.2. مشكلة البحث: 
من اجل تحقيق أهداف البحث فقد وضع مخطط فرضي، ويتضمن متغيرين هما : الشكل( 1 ). أ- المتغير الأول: ويتمثل بالحوافز كمتغيراً مستقل ويضم بعدين : متين

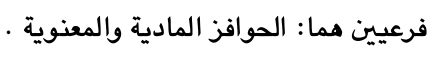

ب- المتغير الثاني: ويتمثل بالرضا الوظيفي كمتغير معتمد، ويضم

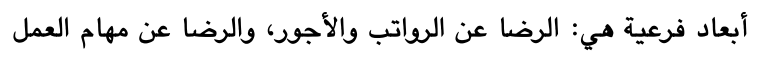
وواجباته، والعلاقة مع الرؤساء والزملاء، والتقدير واحترام الذات.

$$
\text { 5.2. }
$$

1- الفرضية الرئيسة الاولى: توجد علاقة ارتباط معنوية بين الحوافز

$$
\text { وأبعاد الرضا الوظيفي على المستوى الكلي والجزئي. }
$$

2- الفرضية الرئيسة الثانية: يوجد تاثير معنوي للحوافز في أبعاد الرضا الوظيفي على المستوى الكلي والجزئي.
وتتمثل بما سيتوصل اليه البحث مـن استنتاجات، ومـا تطرحسه مـن

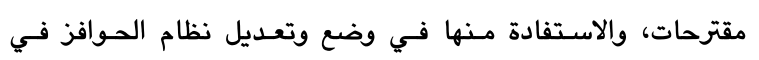

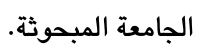
3.2 اهداف البحث: يسعى البحث الى تحقيق الاهداف الاتية: 1- تقديم مفاميم نظرية لقيادة جامعة زاخو حول موضوع الحوافز واهميتها وأنواعها، وعن مفهوم الرضا الوظيفي واهميته وأبعاده في نظميه تحقيق الاهداف التي تسعى الجامعة الوصول اليها . 2- اختبار العلاقة بين المتغيرات المستقلة والمعتمدة. 3- يمكن التوصل من تحليل البيانات إلى تشخيص موضوعي للمشاكل والأسباب التي قد تعيق تدقيق الرضا الوظيفي، ومن ثم مساعدة الجامعة لاتخاذ القرارات المناسبة لمواجهة هذه الأسباب والمشكلات.

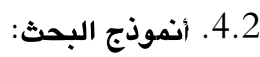

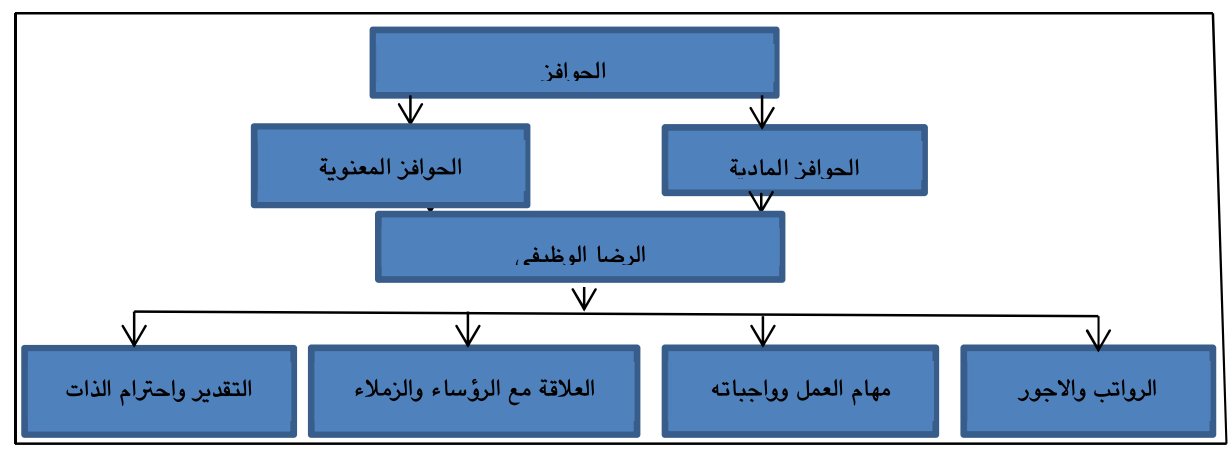

$$
\text { الشكل (1): مخطط البحث الفرضي. }
$$

الفرضيات، وأن اختيار العينة المناسبة يضمن الوصول إلى استنتاجات

وقد قام الباحثون بتوزيع (60) استبانة على الموظفين في جامعة زاخو، وتم استرداد (53) استبانة صالحة للتحليل الاحصائي، ويمعدل

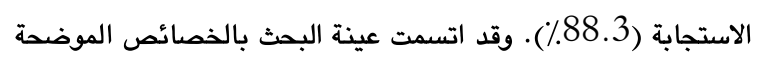

يتحدد مجتمع البحث بجامعة زاخو، ويكتسب اختيار عينة البحث أهمية كبيرة في معظم المجالات المعاصرة في الوقت الصاضر بدءاً من اختيار

\begin{tabular}{|c|c|c|c|}
\hline & & & الجنس \\
\hline \multicolumn{3}{|c|}{ الإناث } & ذكور \\
\hline$\%$ & العدد & $\%$ & العدد \\
\hline \multirow[t]{2}{*}{47.2} & 25 & 52.8 & 28 \\
\hline & & & الحالة الاجتماعية \\
\hline & متزنج & & اعزب \\
\hline$\%$ & العدد & $\%$ & العدد \\
\hline 43.4 & 23 & 56.6 & 30 \\
\hline
\end{tabular}
عنوان البحث ووضع الخطوط العريضة له وحتى الأنتهاء من اختبار

$$
\text { في الجدول (1). }
$$

الجدول (1): الخصائص الشخصية لأفراد عينة البحث 
أوسو ، خيري علي وآخرون/ مجلة العلوم الانسانية لجامعة زاخو، مجلد:6 ، العدد: 1 ، الجزء: 2 ،ص 344- 357، أذار - 2018.

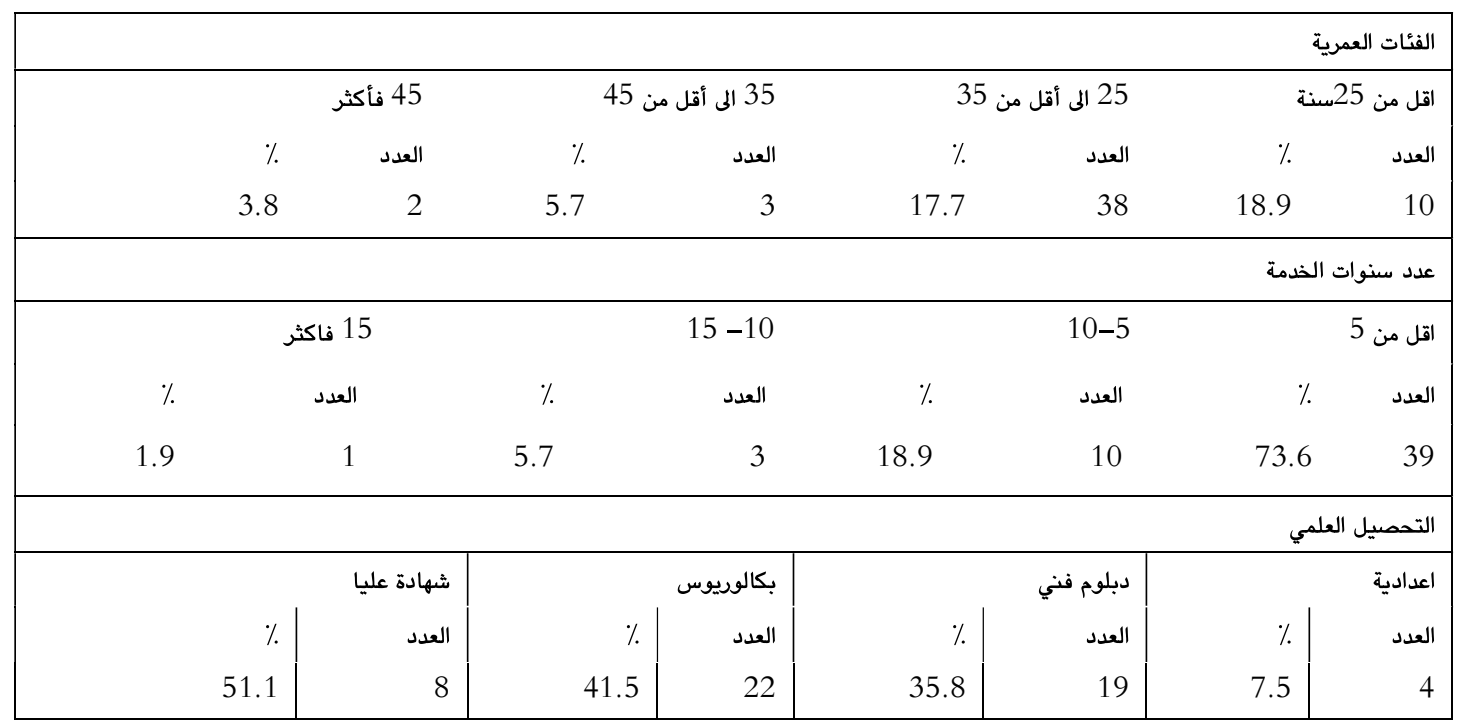

المصدر: اعداد الباحثين اعتمادا على نتائج ( SPSS)

باستمرار نشاطه بكفاءة وفاعلية، وكذلك تحقيق الاهداف التي تحددها

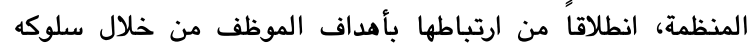
الشخصي او في مجموعته او محيطه الاجتماعي والمادي،وأن الحوافز تشجع على استمرار الجهود المتناسقة بين الرئيس والمؤوس. ومن ناحية اخرى يرى ( ابو شرخ، 2010: 9 9) إن للحوافز دود رئيسي في توفير بيئة عمل مناسبة داخل المنظمة ويتحقق ذلك من خلال مجموعة من الإجراءت فيما يتعلق ببرنامج التحفيز والذي من خلاله يتم تحفيز الموظفين في المنظمة لتقديم كل ما لديهم وفي المقابل فان تجاهل وجود نظام حوافز قانوني وفعال يكفل حقوق وامتيازات الموظفين يعرض المنظمات للعديد من المخاطر التي تؤثر سلباً على مجمل الأداء الوظيفي والسلوكي، وتعتمد دافعية الموظفين بإتجاه تدقيق النتائج المرغوية على أوذان وقيمة وعدالة الحوافز الممنوحة من قبل ادارة

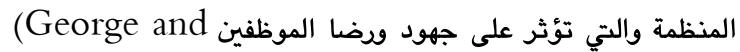
Jones, 2006, 144) ويضيف ( الشرعة، 2014: 158) مجموعة من الشروط لجعل نظام الحوافز في المنظمة علعمل بكفاءة وفاعلية، وتتمثل هذه الشروط بالاتي: 1- - العدالة في تقدىم الصوافز وكفاىتها للموظفين 2- تنوىع الحوافز بحىث تشمل المادي والمعنوي، لاشباع حاجات ورغبات الموظفين. 3- مشاركة الموظفين في وضع نظام الحوافز يساهم على زيادة قناعتهم بها وتحمسهم لها والمحافظة علىىها. 4- تحدى الوقت الملائم الذي تستخدم فىىه الحوافز وخاصة المادىة منها وأن تكون في مواعىد محددة ومتقارية.

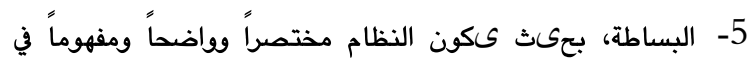
بنوده وصىاغته وحساباته .
يتضع من نتائج الجدول (1) أن ما نسبته (52.8 \%) من الأفراد المبحوثين مم من الذكور، مقابل (43.4٪) من الاناث، وتشير نتائج الحالة الاجتماعية ان اغلب الموظفين من العزاب ويلفت نسبتهم (56.6٪)، مقابل (43.4\% ) من المتزوجين، وتشير نتائج العمر بان

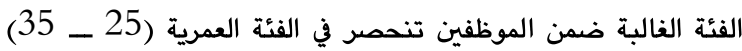
سنة، ويلغت نسبتهم (71.7\%)، وفيما يخص عدد سنوات الخدمة

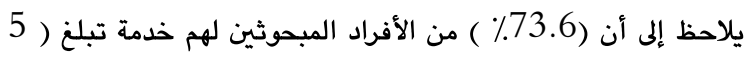

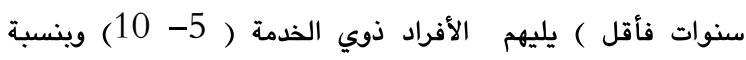
(18.9٪)، وفيما يخص التحصيل العلمي يظهر الجدول أن غالبية الموظفين عينة الدراسة هم من حملة شهادة البكالوريوس وينسبة بلغ (41.5\%) يليهم حاملي شهادة الدبلوم الفني وينسبة (35.8٪). 3. المحور الثاني :الحوافز وابعادها

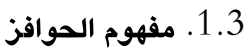

امتم الباحثون وعلماء الإدارة بمفهوم الحوافز لكونها تدفع الموظف نحو

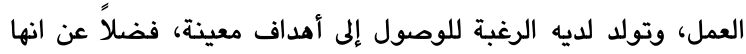
تؤثر في العديد من الظواهر والموضوعات الإدارية ومن اهمها الرضا الوظيفي، وتعد الحوافز بكونها القدرة على مكافأة الموظفين مقابل ما أنجزوه من أعمال وإلتزامهم بالإجراءات والقواعد والتعليمات والأخلاقيات الواجب ملازمتها لسلوكيات الأفراد أثناء أداء واجباتهم الوظيفية ( 441 : Kreitner,2007) .

تعرف الحوافز بكونها مجموعة من العوامل التي تقوم الإدارة بتهيئتها

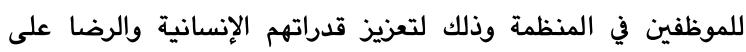
مستوى الفرد والجماعة، ورح الفريق الواحد والتعاون بين ويما يزيد من كفاءة أدائهم (Robbins\&Judge, 2007: 123) وترى ( وميبة، 2013: 26) بأن الحوافز تستخدم للتأثير على القوى الدافعة الموجودة داخل الموظف وتوجيهها بشكل صحيح، ويسمح 
4.المحور الثالث: الرضا الوظيفي وأبعاده

1.4. مفهوم الرضا الوظيفي:

نال الرضا الوظيفي للموظفين أهمية كبيرة من قبل العديد من الباحثين في مجال العلوم الإدارية والدراسات السلوكية وفي مختلف المنظمات منذ مطلع الثلاثينات من القرن الماضي وحتى الأن اذ كان له أثر كبير على ولى اداء العمل والموظفين وإنجازاتهم (الطيب، 2008، 42). وتعد الموارد البشرية الداعم الرئيس لنجاح المنظمات، لذلك لابد من الأمتمام بهم والعمل على إرضائهم وتحقيق متطلباتهم، اذ يترتب على اممالهم انخفاض ادائهم، ومن ثم التاثير على المنظمة فيما يخص الاهداف التي تسعى الى تدقيقها، لذلك أصبح من الضرودي البحث عن حل لهذه المشكلة ويتم ذلك عن طريق تحسين مستوى رضا لديهم ( حويحي، (2008: 9). وقد اتخذت تعريفات الرضا الوظيفي اتجاهات مختلفة ومتنوعة حيث جعلت الاتفاق على تعريف واحد امرا صعباً نظراً لأختلاف النظرة للرضا عن العمل التي تعود الى اختلاف الظرفف الاقتصادية والسياسية والقانونية والمعيشية والبيئية والقيم والمعتقدات وطبيعة الاتجاه الذي

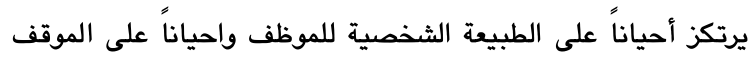
البيئي للعمل (سامية، 2014: 3). ويعد الرضا الوظيفي من وجهة نظر (Stone ) بكونه الحالة التي يتكامل فيها الفرد مع وظيفته ويصبح إنسانا تستغرقه الوظيفة، ويتفاعل معها من خلال طموحه الوظيفي ورغبته نحو التقدم والنمو وتحقيق اهدافه الاجتماعية من خلالها، ويمكن تسمية مذا الفرد بالفرد

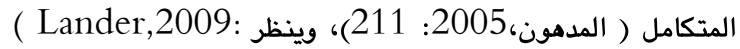
(177الى الرضا الوظيفي بكونه يتركز حول موقف ايجابي او سلبي للموظف تجاه وظيفته ، أي تقديره لوظيفته من حيث ميله له اوكرامته تجاهها. ويركز ( الزيدان، 2014: 10) في تعريفه للرضا الوظيفي على العوامل البيئية،ويشير بكونها مجموعة من العوامل والمؤثرات الخارجية والداخلية المتعلقة بالموظف والعمل الذي يقوم به، وتؤدي هذه العوامل الى الرضا الوظيفي اذا كانت متفقة مع ما يطمح له الموظف من انجازات

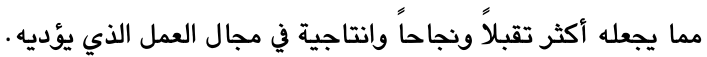
ويرى (عطا والعزاوي، 2014: 114) بأن الرضا الوظيفي هو مدى ئج قناعة الموظف بالجهد الذي يبذله في انجاز المهام الموكلة اليه، وانعكاس ذلك على مدى امكانية تحقيق حاجاته بكفاءة وفاعلية ويما ينعكس

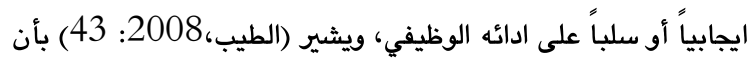
الرضا الوظيفي هو الشعود بالارتياح والسرود الناتج من إثباع الحاجات والرغبات ذات القيمة العالية عند الموظف. ويشير الرضا الوظيفي إلى صفات ومشاعر الناس تجاه عملهم، اي

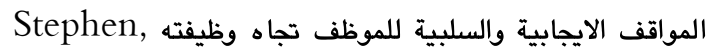

6- ضرورة الاهتمام بمراجعة نظام الحوافز بشكل دائم ومستمر من

أجل تطويرها بما تلاءم مع المتغيرات في البيئة الخارجية للمنظمة. ويموجب ما سبق يمكن القول بان الحوافز عبارة عن المؤثرات والعوامل الخارجية تساهم على رفع الروح المعنوية للموظفين، ورفع أدائهم واشباع حاجاتهم ورغباتهم وضمان ولائهم التنظيمي.

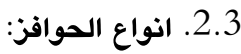

تتباين مكونات وعناصر الحوافز من منظمة لأخرى وأمميتها من مجتمع لآخر، إلا أن أغلب الباحثين وممارسي الإدارة يجمعون على إن الحوافز تتكون من بعدين مما البعد المادي والبعد المعنوي ( ) Houlds and Jirasinghe2006:198 )، وفيما ياتي شرح لكل منهما: 1- الحوافز المادية: تتشكل الحوافز المادية من الأجر على أساس الساعة أو الأسبوع أو اليوم أو السنة، إضافة لزيادات بالدفع على أساس الأداء، وكذلك المزايا كالتأمين الصحي والمشاركة في الأرياح ويرامج العناية بالطفولة ونظام الإجازات والتقاعد ( حمدان والساكت، 2011: 15:)، وينبغي على المنظمات الحفاظ على مستوى عالي لاداء

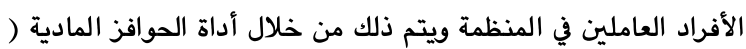
.(Osa,2014:64 وتتمثل الصوافز المادية في كل ما يدفع للموظفين بشكل نقدي أو

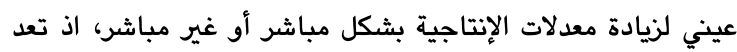
العلاوات والمشاركة في الأرباح والتأمين الوظيفي والاجتماعي حوافز مادي، ويمثل الأجر من امم الحوافز المادية ( خضير، 2014: 14: ويؤكد ( الملوح،2014: 5ادي، ويمل الأن من الحمافز المادية تكون ذات طابع مادي او مالي او نقدي تشبع حاجات الانسان ورغباته الأساسية وتدفع وتحفز الموظفين الى بذل جهود كبيرة في العمل مما يساعد الى ارتفاع مستوى المنظمة ويقاءها. 2- الحوافز المعنوية: تساعد الحوافز المعنوية الموظفين على تحقيق حاجاته الأخرى النفسية والاجتماعية وتعمل على زيادة الرحح المعنوية للموظفين من خلال توجيه للعمل ( حمدان والساكت، . 2011

وتشمل الحوافز المعنوية الترقية وتقدير جهود الموظفين وإشراكهم في ادارة المنظمة وضمان استقرار العمل وتفويض الصلاحيات (ابو شرخ،

( 11 :2010

وتشبع الحوافز الحاجات الفردية والجماعية الذاتية والتي ترتبط بالحالة النفسية السلوكية للموظفين بهدف رفع معنوياتهم وتحسين الجو المحيط بالعمل، وابرزت الكثير من الدراسات والأبحاث الميدانية

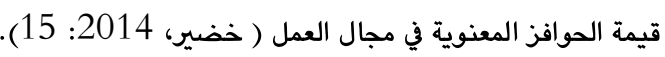


1- الرضا عن الأجور: تعد الأجور وسيلة مهمة لإثباع الحاجات المادية والاجتماعية للموظفين، ويعد قوة شرائية تساعده لتامين حياته

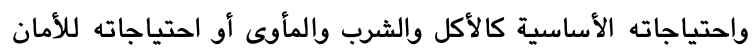
والاندماج في العلاقات الاجتماعية بما يضمن تحقيق مكانة ويروذ على مستوى المنظمة، لذلك فان رضا الموظف وشعوره بالتقدير وإنتاجيته يتوقف على مدى ملائمة الاجور للمجهودات المبذولة في الوظيفته المطلوبة، ولا شك أن الأجور تعد من أهم العوامل التي تساعد على ملى ملى إيجاد علاقة طيبة بين الموظفين والإدارة إذ أن درجة رضا الموظف عن عمله يتوقف إلى حد كبير على قيمة ما يحصل عليه نقدا أو عينا لذلك فإن العناية بتحقيق الأجر العادل أو الاهتمام بوضع سياسة رشيدة للأجور وملحقاتها يعتبر نجاح برامج إدارة الموارد البشرية في المنظمة . 2- الرضا عن مهام العمل وواجباته: تتضمن الوظيفة، ويعد مهام العمل وواجباته وقنوات الاتصال وغيرما، وهي نتيجة للموظف لكسب

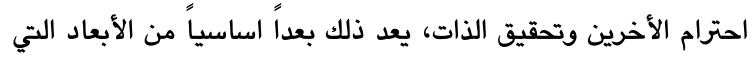
يأخذها الرضا الوظيفي بنظر الاعتبار، لذلك فأن الموظفين الذين يشعرون بان الوظيفة تجعلهم يكسبون احترام الأخرين، وان مهامهم وواجباتهم تتناسب مع قدراتهم ودغباتهم سوف يعزذ ويحسن قناعتهم بالعمل المطلوب منهم ويزداد رضاهم الوظيفي عن عملهم (مطوف، .) 2016 ويؤكد (محمود وانصاف، 2012: 65 ) ان تنوع مهام العمل لن يؤدي الى حدوث الملل في الوظيفة بل يزداد الرضا،كما يشعر الفرد بأهميته كلما منحت له صلاحيات لانجاز وظيفته ويذلك يزداد رضاه عل العمل، وتلعب محتوى الوظيفة وظروفها دوراً مهماً في تحديد الرضا الوظيفي يدي وذلك من حيث نوع مهام العمل وحجمه ونمطه وكذلك بما تتيحه الوظيفة من إمكانية للموظف لإظهار قدراته وإبداعاته وخبراته وإمكانياته مما يؤدي الى تدقيق رضا عالي بالإضافة الى وجود فرص في النمو والتقدم

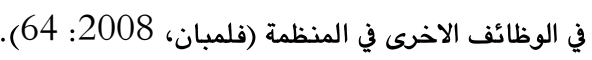
3- العلاقة مع الرؤساء والزملاء: ويقصد بهم الأفراد الذين يختلط بهم الفرد ويعاشرهم ويعمل معهم لانجاز الانشطة والمهام (خوين، 2012:

وتلعب علاقة الموظف بزملائه في وحدة العمل دوراً مهما في مدى تعلقه بوظيفته واندماجه في العمل، وتسعى المنظمات دائماً لتوفير أجواء تسود فيها علاقات طيبة بين العاملين وتوفير فرص الصداقة والتعاون فيما بينهم وكذلك توافر علاقات طيبة بينهم وبين الإدارة و ذلك لبناء جسور الثقة بالإدارة الى جانب احترام الموظفين لقدرات بعضهم البعض وتوافقهم الاجتماعي المتبادل، والعمل على بناء وحدة اجتماعية

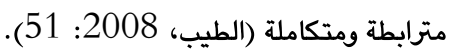
ويولد أسلوب الرؤساء في التعامل مع الموظفين الأجواء الوظيفية الهادفة من خلال المشاركة بأتخاذ القرارات ورسم السياسات وتشجيعهم
(12) (مطوف،2016: 350 ) الرضا الوظيفي بانه شعور الموظف سواء

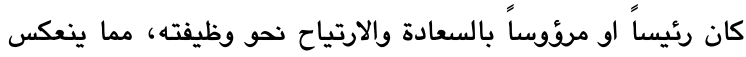
على استعداده الذهني والبدني على بذل اقصى قدر ممكن من العطاء

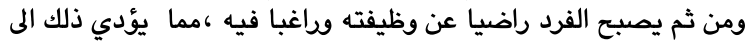
بقاء و نمو وتوسع وتطور المنظمة. ويموجب ما تقدم يتبين بان الرضا الوظيفي مفهوم معقد ومتعدد الأوجه يمكن أن يعني أشياء مختلفة لأناس مختلفين، وعليه فالرضا الوظيفي عبارة عن احساس داخلي للموظف تجاه وظيفته ويشعر بالارتياح والسعادة نفسياً نتيجة لإثباع حاجاته ورغباته من خلال مزاولته لها، وله القدرة على القيام بالواجبات والمهام المطلوية وانجازها بأعلى كفاءة وفاعلية. 2.4. أهمية الرضا الوظيفي تعد الموارد البشرية الثروة الحقيقية والمحور الأساسي للإنتاج في منظمات الأعمال، اذ ان المعدات والأجهزة الحديثة مهما بلغ تطورهما ستبقى غير مفيدة ان لم تستغل بشكل صحيح، وان لم يتوفر العقل البشري الذي يديرها ويحركها ويستخدمها، لذلك اصبح من الضروي الحرص على توفير درجة عالية من الرضا الوظيفي للموظفين في المنظمة لان ذلك سيسهم في التزام هؤلاء بمنظماتهم ووفائهم لتعهداتهم نحوما

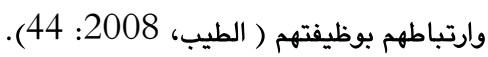
ويشير (فلمبان،2008: 45- 46) بان هناك عدداً من الاسباب التي تدعو الى الاهتمام بالرضا الوظيفي، وتتمثل بماياتي : 1- دوران عمل أقل، فالموظفون يسعون الى البقاء فترة زمنية طويلة ان كانوا راضين عن مهام عملهم. 2- اقل غياباً عن العمل، ان الموظفون السعداء في العمل يتطلعون الى الى تقديم المزيد من الجهود لخدمة الزبائن.

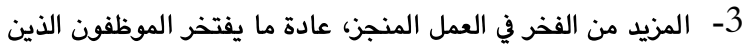
يشعرون بالرضا في وظائفهم ان يكونوا اكثر دقة في العمل. 4- التعامل مع حالات الضغط وتقديم خدمات افضل الى الزبائنفالموظفون الراضون عن عملهم يميلون العمل الى التكيف مع مشاكل العمل واكثر استعداداً لإجراء تغييرات والتفاعل مع الناس بطريقة اكثر إيجابية مع الزيائن مما يجعلهم يرغبون في العودة والاستفادة من المزيد

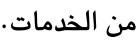
3.4. أبعاد الرضا الوظيفي تتباين وجهات نظر الكتاب والباحثين بخصوص أبعاد الرضا الوظيفي الا انها تنحصر في مجموعة أبعاد رئيسة سيعتمدما البحث لوجود قدر كبير من الاتفاق عليها، وتتمثل بما ياتي:(منصور، 2010) و (خوين،2012) و(الثبيتي والعنزي، 2014 ). 
ويشير (Paul,2004: يعطيه الموظف لذاته، يعني وجود معرفة واسعة وشاملة عن الذات بمختلف جوانبه، وتشير الذات الى مجموعة خاصة من الافكار والاتجاهات التي تكونها ذاتنا في اي لحظة من الزمن، اي انها ذلك البناء المعرفي المنظم الذي ينشأ من الوعي بأنفسنا، ويمثل تقدير الذات

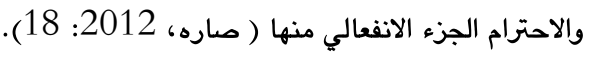

1.5. وصف متغيرات الحوافز
على تنمية روح الولاء التنظيمي والإخلاص والصدق والصرص الدائم على المنظمة (حويحي، 2008: 19 19. 4- التقدير واحترام الذات: ان توفر التقدير واحترام الذات للموظف من خلال عمله سواء كان بسبب المركز الذي يشغله أو بسبب طبيعة وظيفته ووجهة عمله ومعرفة أفراد المجتمع لهذه المكانة أو المنظمة الذي ينتمي إليها يؤدي إلى رضا الموظف عن العمل الذي يقوم به

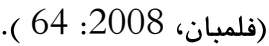

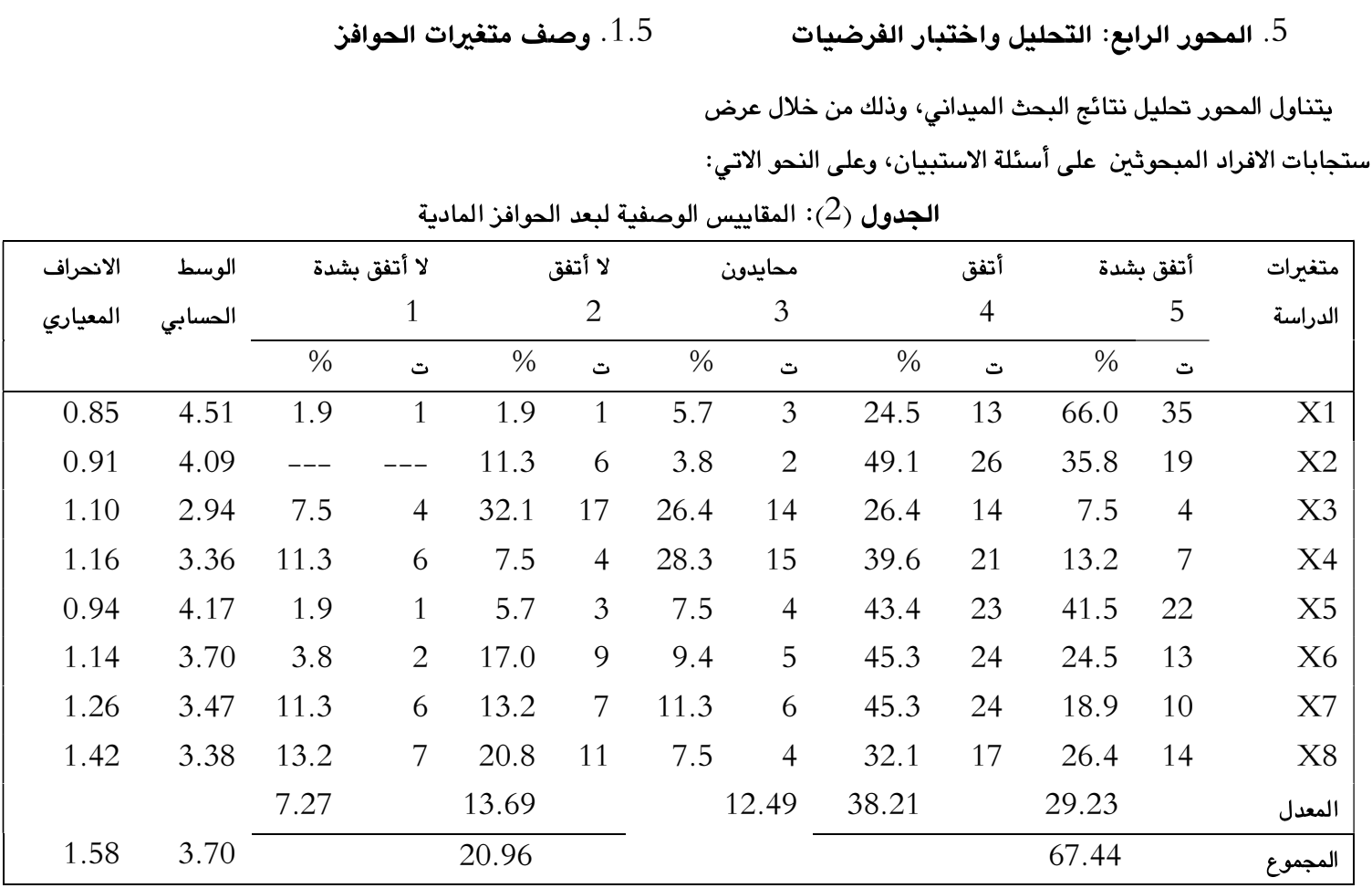

المصدر: من إعداد الباحثين أعتماد على نتائج (SPSS).

الوظيفة في الجامعة على توفيرالاجور التي تتناسب مع المؤهلات

الوظيفية.

2- وصف الحوافز المعنوية: يتبين من الجدول (3) الذي يمثل المتغيرات (X17-X9) والخاصة بيعد الحوافز المعنوية، إلى أن (61.21\%) من الموظفين المبحوثين متفقون مع عبارات مذا البعد، ويلغ معدل المحايدين (19.29\%)، فيما بلغ معدل غير المتفقين (18.63\%)، ويمتوسط حسابي (3.80)، وانحراف معياري (2.22) ، مما يعني توافر العديد من المؤشرات التي تدل على اتفاق عينة البحث على دود الحوافز المعنوية في دفع الافراد ويذل المزيد من الجهود في العمل لدى الجامعة المبحوثة، وأن أعلى نسبة اتفاق كانت على المؤشر لهر (X12)، اذ جاء بمعدل قدره (83.0٪)، ويشير ذلك الى ان التقدير والاحترام من قبل الرؤساء من امم الامور التي تدفع الموظفين للعمل، وكانت اقل نسبة اتفاق على المؤشر(X13) اذ جاء بمعدل قدره ( 41.5٪)، ويشير ذلك الى ضعف او محدودية اتاحة الجامعة للموظفين فرص المشاركة على وضع الخطط المستقبلية.
1- وصف الحوافز المادية: تبين من الجدول (2) الذي يمثل المتغيرات (X8-X1 ) والخاصة ببعد الحوافز المادية ، إلى أن

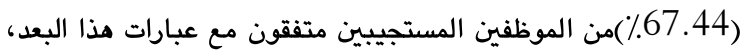
ويلغ نسبة المحايدين (12.49٪)، فيما بلغ نسبة غير المتفقين (20.96٪)، ويمتوسط حسابي (3.70)، وانحراف معياري (1.58)، مما يعني توافر العديد من المؤشرات التي تدل على اتفاق عينة البحث على دور الحوافز المادية في دفع الافراد على بذل الجهود في العمل لدى الجامعة المبحوثة، وأن أعلى نسبة اتفاق كانت على المؤشر(X1) ، اذ

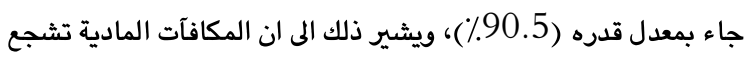
الموظفين على بذل المزيد من الجهد والمثابرة لأداء العمل في الجامعة، ويليه المتغيران(X2) و (X5)، اذ جاءا بمعدل قدره (84.9٪) لكل منهما، ويشير ذلك الى ان الموظفين يشعرون باهمية الحوافز والمكافات التي تمنحها الجامعة لهم، كما توفر الجامعة النقل للموظفين من والى

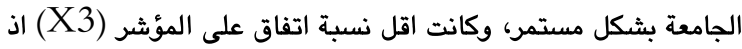
جاء بمعدل قدره ( 33.9٪)، ويشير ذلك الى ضعف او محدودية دور 
الجدول (3): المقاييس الوصفية لبعد الحوافز المعنوية

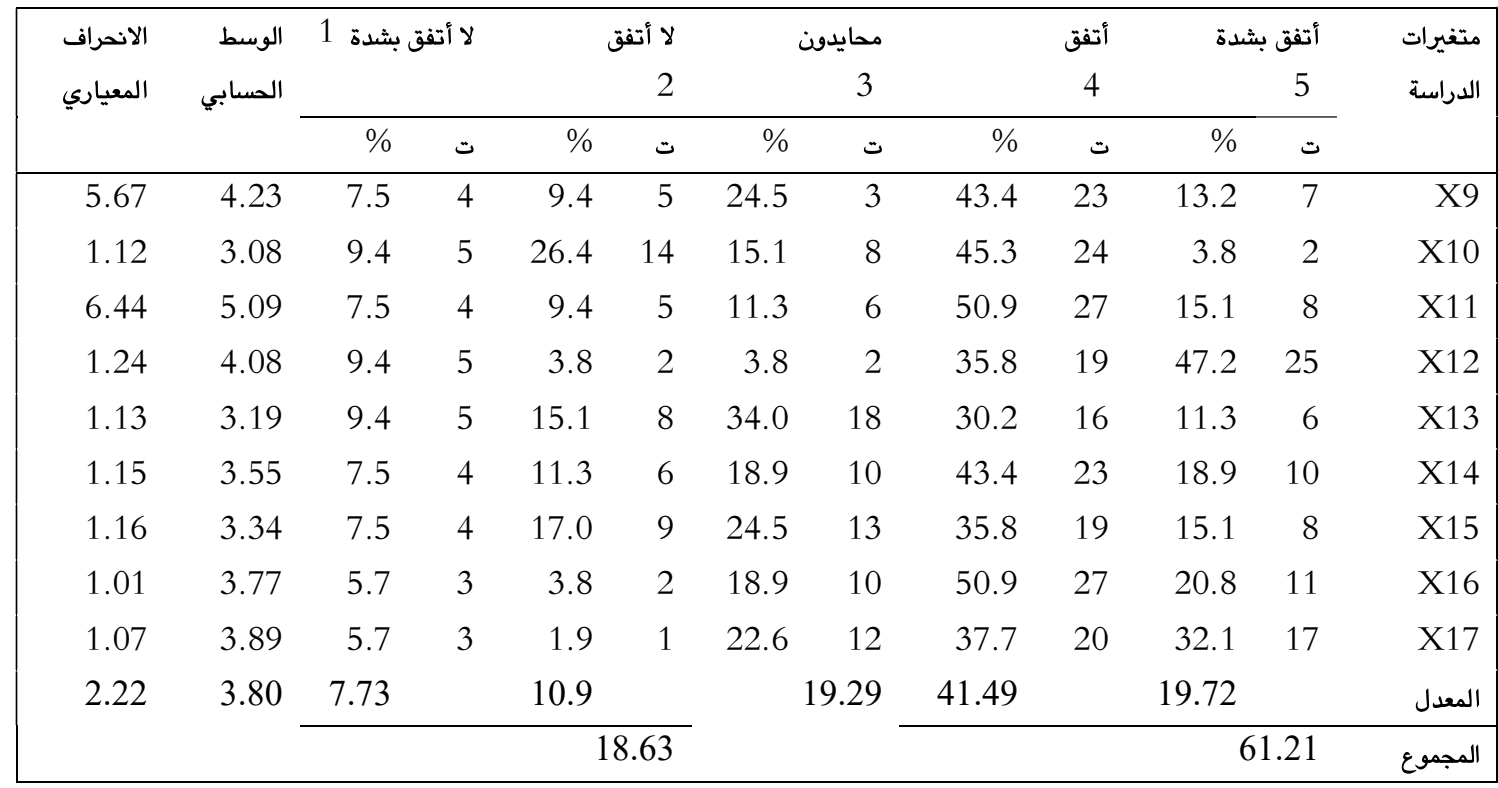

المصدر: من إعداد الباحثين أعتمادا على نتائج (SPSS).

(56.9٪)، ويمتوسط حسابي (2.51)، وانحراف معياري (1.46)، 2.5. مما يعني ضعف او محدودية رضا الموظفين في الجامعة عن الرواتب تشير معطيات الجدول(4) الى التوزيعات التكرارية والنسب المئوية

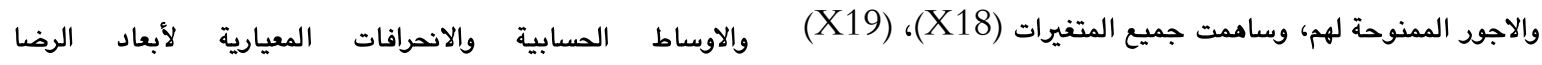

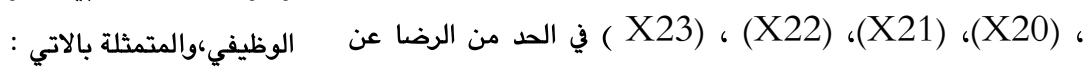
الرواتب والاجور الممنوحة للموظفين،وجاءت بنسب تراوحت ما بين 1- الرضا عن الرواتب والاجور: تشير النسب المئوية في الجدول

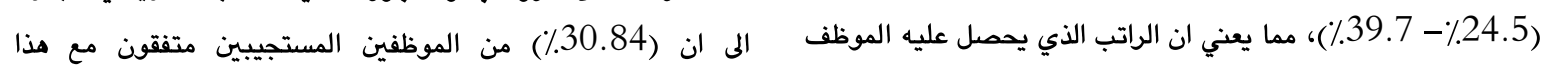
يسد احتياجاته بشكل محدود، وضعف تناسب الاجور المدفوعة مع المتفير،ويلغ معدل المحايدين (12.27٪)، فيما بلغ معدل غير المتفقين

عبء العمل

تفة الجدول (4): المقاييس الوصفية لأبعاد الرضا الوظيفي

\begin{tabular}{|c|c|c|c|c|c|c|c|c|c|c|c|c|c|}
\hline \multirow{2}{*}{ الانحراف } & \multirow{2}{*}{ الوسط الحسابي } & \multicolumn{2}{|c|}{ لا أتفق بشدة } & \multicolumn{2}{|r|}{ لا أتفق } & \multicolumn{2}{|c|}{ محايدون } & & أتفق & \multicolumn{2}{|c|}{ أتفق بشدة } & \multicolumn{2}{|c|}{ المتغيرات } \\
\hline & & & 1 & & 2 & & 3 & & 4 & & 5 & & \\
\hline 1.61 & 2.47 & 47.2 & 25 & 9.4 & 5 & 9.4 & 5 & 17.0 & 9 & 17.0 & 9 & X18 & .8 \\
\hline 1.31 & 2.55 & 26.4 & 14 & 28.3 & 15 & 18.9 & 10 & 17.0 & 9 & 9.4 & 5 & X19 & .3 \\
\hline 1.54 & 2.43 & 39.6 & 21 & 24.5 & 13 & 5.7 & 3 & 13.2 & 7 & 17.0 & 9 & $\mathrm{X} 20$ & $\overline{3}$ \\
\hline 1.49 & 2.89 & 26.4 & 14 & 17.0 & 9 & 17.0 & 9 & 20.8 & 11 & 18.9 & 10 & $\mathrm{X} 21$ & . \\
\hline 1.37 & 2.34 & 37.7 & 20 & 24.5 & 13 & 13.2 & 7 & 15.1 & 8 & 9.4 & 5 & $\mathrm{X} 22$ & $\overrightarrow{x_{1}}$ \\
\hline 1.43 & 2.40 & 39.6 & 21 & 20.8 & 11 & 9.4 & 5 & 20.8 & 11 & 9.4 & 5 & $\mathrm{X} 23$ & 2 \\
\hline \multirow[t]{2}{*}{1.46} & 2.51 & 36.15 & & 20.75 & & 12.27 & & 17.32 & & 13.52 & & & | المعدل \\
\hline & \multicolumn{5}{|c|}{56.9} & & & & \multicolumn{3}{|c|}{30.84} & \multicolumn{2}{|c|}{ المعدل العام } \\
\hline 1.30 & 3.17 & 15.1 & 8 & 20.8 & 11 & 5.7 & 3 & 49.1 & 26 & 9.4 & 5 & X24 & \\
\hline 1.25 & 3.45 & 11.3 & 6 & 11.3 & 6 & 17.0 & 9 & 41.8 & 22 & 18.9 & 10 & $\mathrm{X} 25$ & 3 \\
\hline 1.19 & 3.47 & 7.5 & 4 & 15.1 & 8 & 18.9 & 10 & 39.6 & 21 & 18.9 & 10 & X26 & $.3 \quad \frac{3}{9}$ \\
\hline 7.06 & 4.30 & 7.5 & 4 & 18.9 & 10 & 18.9 & 10 & 37.7 & 20 & 15.1 & 8 & X27 & $\frac{9}{2} \quad \frac{3}{13}$ \\
\hline 1.34 & 2.92 & 17.0 & 9 & 28.3 & 15 & 13.2 & 7 & 28.3 & 15 & 13.2 & 7 & X28 & $\overline{3}$ \\
\hline 1.34 & 3.02 & 18.9 & 10 & 18.9 & 10 & 15.1 & 8 & 35.8 & 19 & 11.3 & 6 & X29 & \\
\hline \multirow[t]{3}{*}{2.25} & 3.39 & 12.88 & & 18.88 & & 14.8 & & 38.72 & & 14.47 & & & المعدل \\
\hline & & & & 31.76 & & & & & & 53.19 & & & \\
\hline & & & & & & & & & & & & \multicolumn{2}{|c|}{ المعدل العام } \\
\hline 1.28 & 3.75 & 11.3 & 6 & 5.7 & 3 & 11.3 & 6 & 39.6 & 21 & 32.1 & 17 & X30 & \\
\hline 1.26 & 3.72 & 13.2 & 7 & --- & --- & 17.0 & 9 & 41.5 & 22 & 28.3 & 15 & X31 & 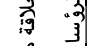 \\
\hline 1.36 & 3.42 & 18.9 & 10 & 1.9 & 1 & 18.9 & 10 & 39.6 & 21 & 20.8 & 11 & X32 & \\
\hline
\end{tabular}


أوسو ، خيري علي وآخرن/ مجلة العلوم الانسانية لجامعة زاخو، مجلد:6 ، العدد: 1 ، الجزء: 2 ،ص 344- 357، أذار - 2018.

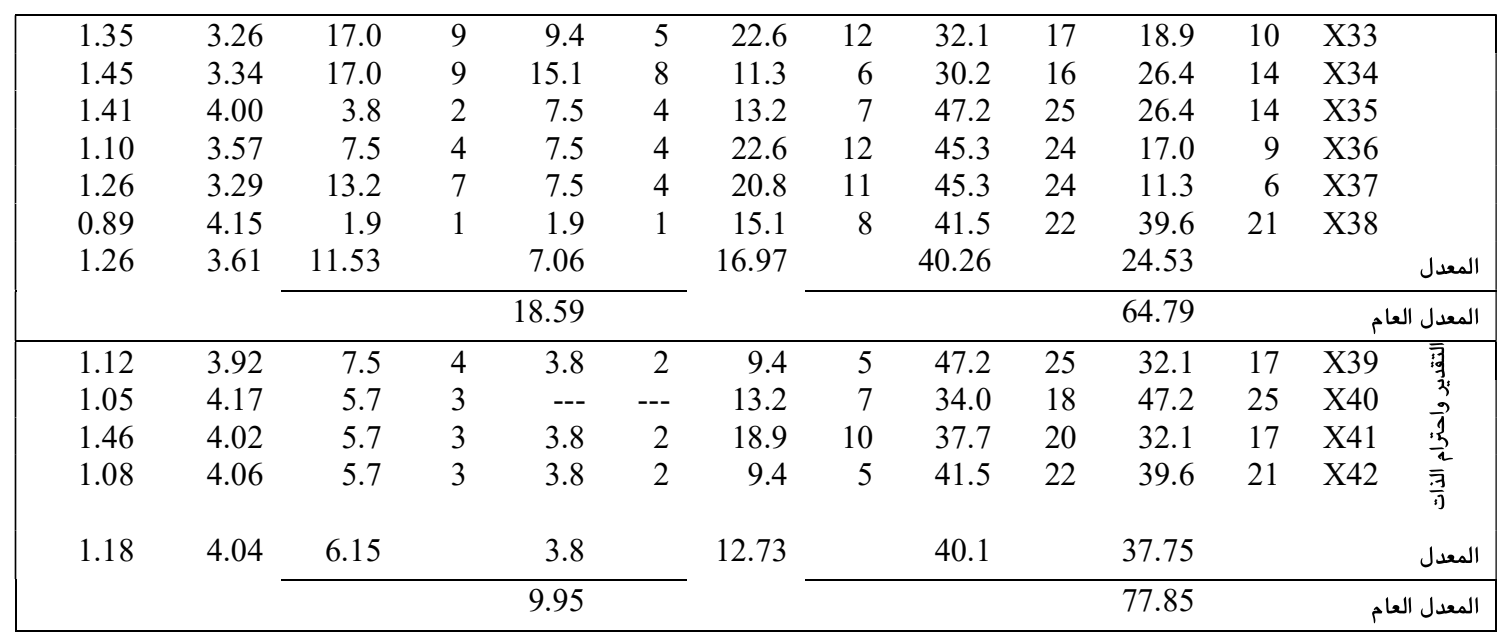

المصدر: إعداد الباحثين أعتمادا على نتائج (SPSS).

جميع المتغيرات في تعزيز هذا البعد وجاءت بنسب تراوحت ما بين

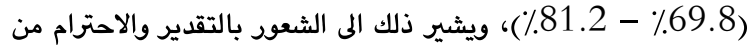
جميع الموظفين داخل الجامعة، وان العمل في الجامعة مصدر فخر وتقدير من قبل العائلة، ويمكن العمل في الجامعة الموظفين من الحصول على ما يستحقونه من تقدير، واخيراً توفر الوظيفة في الجامعة مركزاً اجتماعياً جيدا تتناسب مع طموحات الموظف. 3.5.تحليل علاقات الارتباط تشير نتائج الجدول (5) الى الاتي: 1- وجود علاقة ارتباط معنوية بين متغير الحوافز ومتغير الرضا الوظيفي على المستوى الكلي، ويؤكد ذلك قيمة معامل الارتباط البالغ

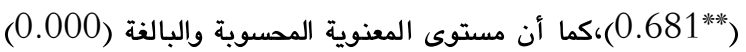
كانت أقل من مستوى المعنوية للبحث والبالغة (0.05)، ويشير ذلك مسكويه انه كلما زاد امتمام جامعة زاخو بالحوافز سيساهم ذلك في تعزيز الرضا الوظيفي لدى الموظفين .

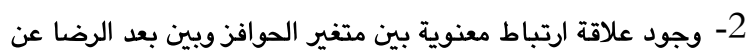

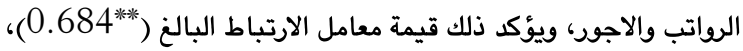
كما أن مستوى المعنوية المحسوية والبالغة (0.000) كانت أقل من مستوى المعنوية للبحث والبالغة (0.05)، ويشير ذلك انه كلما زاد امتمام جامعة زاخو بالحوافز سيسامم ذلك في تعزيز الرضا عن الرواتب والاجور لدى الموظفين .

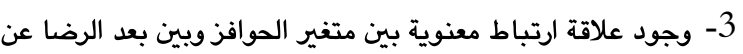
مهام العمل وواجباته، ويؤكد ذلك قيمة معامل الارتباط البالغ

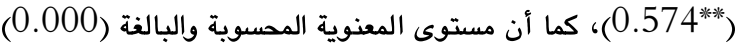
كانت أقل من مستوى المعنوية للبحث والبالغة (05.05)، ويشير ذلك انه كلما زاد امتمام جامعة زاخو بالحوافز سيساهم ذلك في تعزيز الرضا

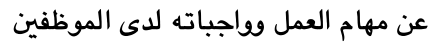
4- وجود علاقة ارتباط معنوية بين متغير الحوافز مجتمعة وبين بعد الرضا عن العلاقة مع الرؤساء والزملاء، ويؤكد ذلك قيمة معامل الارتباط
كما ان الراتب الحالي غير كافي على سد متطلبات المعيشة الحالية، وان الراتب الحالي لا يحقق الصد الادنى من الرفاهية، وان العمل والمهام الذي يقوم بها الموظف لا تتناسب مع الراتب الذي يحمل عليه، وان الراتب الذي يحصل عليه الموظف لايتناسب إلا بشكل محدود مع الوضع الاقتصادي السائد في المجتمع، ويعزف الباحثون ذلك الى الازمة المالية التي حصلت في اقليم كوردستان.

2- الرضا عن مهام العمل وواجباته: تشير النسب المئوية في الجدول الى ان (3.19\%) من الموظفين المستجيبين متفقون مع مذا المتغير، ويلغ نسبة المحايدين (14.8\%)، فيما بلغ نسبة غير المتفقين

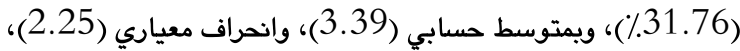

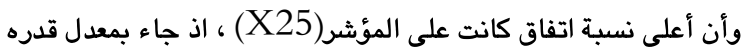
(60.7\%)، ويشير ذلك الى ان المهام المطلوية في العمل واضحة ودقيقة، وكانت اقل نسبة اتفاق على المؤثر (X28) اذ جاء بنسبة قدره ( ) 41.5٪)، ويشير ذلك الى ضعف او محدودية وجود عدالة في توزيع العمل

بين الموظفين الأقسام العلمية للجامعة . 3- العلاقة مع الرؤساء والزملاء: تشير النسب المئوية في الجدول الى ان (64.79\%) من الموظفين المستجيبين متفقون مع مذا المتغير، ويلغت نسبة المحايدين (16.97\%)، فيما بلغ نسبة غير المتفقين (18.59٪)، ويمتوسط حسابي (3.61)، وانحراف معياري (1.26)، وأن أعلى نسبة اتفاق كانت على المؤشر(X38) ، اذ جاءت بنسبة قدره (81.1\%)، ويشير ذلك الى تبادل الزملاء مشاعر الود والاحترام،

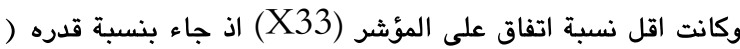
50.0٪)، ويشير ذلك الى امتمام الرئيس بدرجة متوسطة حول ارشاد

$$
\text { الموظفين نحو العمل وسماع مقترحاتهم · }
$$
4- التقدير واحترام الذات: تشير النسب المئوية في الجدول الى ان (77.85\%) من الموظفين المستجيبين متفقون مع هذا المتفير،ويلغ نسبة المحايدين (12.73\%)، فيما بلغ نسبة غير المتفقين (95.95\%)،

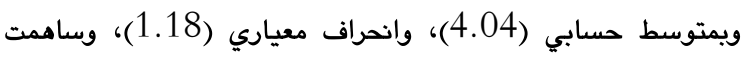


ويشير ذلك انه كلما زاد امتمام جامعة زاخو بالحوافز سيسامم ذلك في تعزيز الرضا عن العلاقة مع الرؤساء والزملاء لدى الموظفين.
البالغ (0.574**)، كما أن مستوى المعنوية المحسوية والبالغة

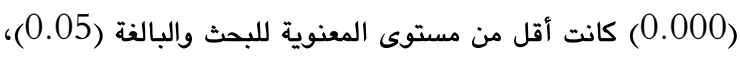

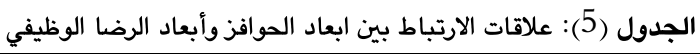

\begin{tabular}{|c|c|c|}
\hline المعنوية & سبيرمان & الفرضيات \\
\hline 0.000 & $0.681^{* * *}$ & توجد علاقة ارتباط معنوية بين الحوافز مجتمعة وأبعاد الرضا الوظيفي مجتمعة \\
\hline 0.000 & $0.684^{* *}$ & توجد علاقة ارتباط معنوية بين الحوافز مجتمعة والرضا عن الرواتب والاجور منفردة \\
\hline 0.000 & $0.574^{* *}$ & توجد علاقة ارتباط معنوية بين متغير الحوافز ويين متغير الرضا عن مهام العمل وواجباته \\
\hline 0.000 & $0.574^{* *}$ & توجد علاقة ارتباط معنوية بين متغير الحوافز وبين بعد الرضا عن العلاقة مع الرؤساء والزملاء \\
\hline 0.000 & $0.483^{* *}$ & توجد علاقة ارتباط معنوية بين متغير الحوافز وبين بعد الرضا عن التقدير واحترام الذات \\
\hline
\end{tabular}

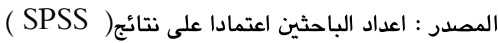

انه كلما زاد امتمام جامعة زاخو بالحوافز سيساهم ذلك في تعزيز التقدير

واحترام الذات لدى الموظفين.

وعليه تشير المعطيات السابقة على تحقق الفرضية الرئيسة الاولى التي تنص على وجود علاقة ارتباط معنوية بين الحوافز وأبعاد الرضا

$$
\text { الوظيفي على المستوى الكلي والجزئي. }
$$

الجدول (6): تاثير الحوافز في ابعاد الرضا الوظيفي

\begin{tabular}{|c|c|c|c|c|c|}
\hline Sig & $\mathrm{F}$ & R2 & B & ابعاد الرضا الوظيفي & \\
\hline 0.000 & 31.55 & 0.468 & 0.863 & الرواتب والاجور & \\
\hline 0.008 & 7.75 & 0.329 & 0.668 & ههام العمل وواجباته & $\overline{1}$ \\
\hline 0.000 & 23.57 & 0.321 & 0.564 & العلاقة مع الرؤساء والزملاء & $\overrightarrow{9}$ \\
\hline 0.000 & 23.38 & 0.233 & 0.560 & التقدير واحترام الذات & \\
\hline 0.000 & 36.47 & 0.464 & 0.664 & المؤشر الكلي & \\
\hline
\end{tabular}

المصدر : من اعداد الباحثين اعتمادا على نتائج( (SPSS)

2- وجود تأثير معنوي موجب للحوافز مجتمعة في الرضا عن الرواتب

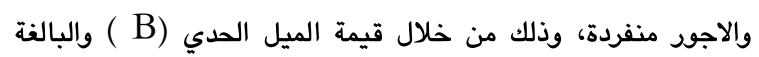
(0.863)،والذي يعني ان زيادة مقداره (1 \%) في ابعاد الحوافز سيؤدي الى زيادة مقداره (86.3\%) في الرضا عن الرواتب والاجور، ويدعم ذلك قيمة (F) المحسوية والبالغة (31.55)، وهي اكبر من قيمتها الجدولية والبالغة (4.042) ،كما أن مستوى المعنوية المحسوية والبالغة

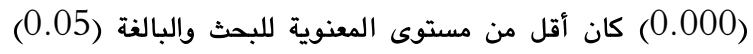
وضمن درجتي حرية (1-51) ، ويلغت القدرة التفسيرية للمتغير

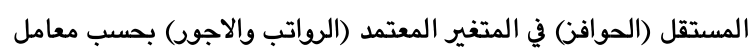

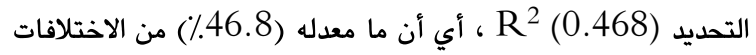

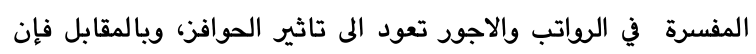

(53.8\%) من الاستجابة تعود لمتغيرات أخرى خارج نطاق البحث. 3- وجود تأثير معنوي موجب للحوافز مجتمعة في الرضا عن مهام

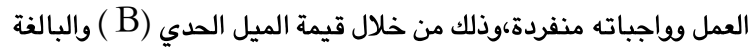
(0.668)،والذي يعني ان زيادة مقداره (1 \%) في ابعاد الحوافز سيؤدي مئه
5- وجود علاقة ارتباط معنوية بين متغير الحوافز ويين بعد الرضا عن التقدير واحترام الذات، ويؤكد ذلك قيمة معامل الارتباط البالغ

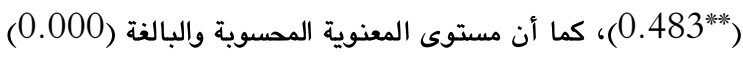
كانت أقل من مستوى المعنوية للبحث والبالغة (0.05)، ويشير ذلك

4.5 ـ تحليل علاقات التاثير
1- وجود تأثير معنوي موجب للحوافز مجتمعة في ابعاد الرضا الوظيفي مجتمعة، وذلك من خلال قيمة الميل الددي (B) ) والبالغة (0.664)، والذي يعني ان زيادة مقدارما (1 \%) في ابعاد الحوافز سيؤدي الى زيادة مقدارها (66.4\%) في الرضا الوظيفي بابعاده

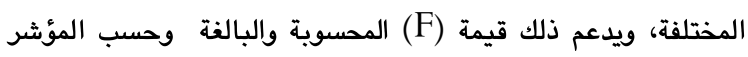
الكلي (36.47)، وهي اكبر من قيمتها الجدولية والبالغة (4.042) كما أن مستوى المعنوية المحسوية والبالغة (0.000) كان أقل من

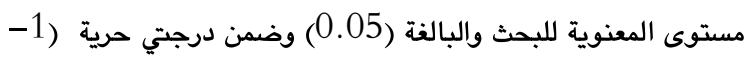

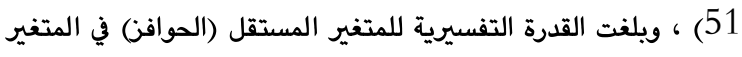

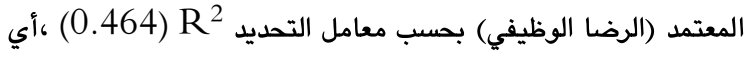
أن ما معدله (46.4\%) من الاختلافات المفسرة في الرضا الوظيفي

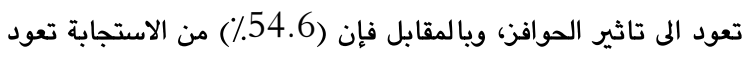
لمتغيرات أخرى خارج نطاق البحث. 
6.المحور الخامس: الاستنتاجات والمقترحات

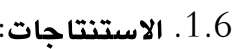

1- تبين ان المكافأت المادية تشجع الموظفين على بذل المزيد من

الجهد والمثابرة لأداء العمل في الجامعة.

2- ضعف أو محدودية دور الوظيفة في الجامعة على توفير الاجور التي

$$
\text { تتناسب مع المؤهلات الوظيفية للموظفين. }
$$

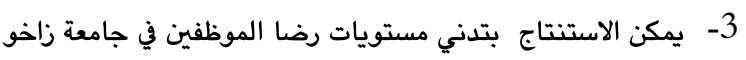

عن الرواتب والاجور الممنوحة لهم ،ويعز الباحثون ذلك الى الازمة

$$
\text { المالية التي الحاصلة في اقليم كوردستان · }
$$

4- تبين ضعف او محدودية العدالة في توزيع العمل بين الموظفين في

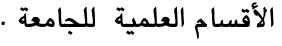

5- يمكن الاستنتاج بان استخدام الجامعة المبحوثة لأبعاد الحوافز

سيعزز ذلك من تحقيق الرضا الوظيفي للموظفين في الجامعة.

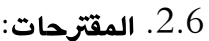

1- ضرورة وجود نظام حوافز فعال يعمل على رفع الرحح المعنوية

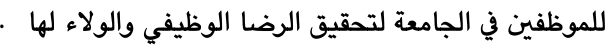

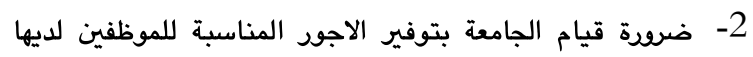
طالما ان الاجور لا تتناسب مع المؤهلات الوظيفية للموظفين. 3- ضروة قيام الجامعة بايجاد الحلول المناسبة للاجور والرواتب الممنوحة للموظفين لعدم قدرتها على تلبية الصد الادنى من الاحتياجات للموظفين. 4- ضرورة قيام الجامعة باعادة النظر في توزيع العمل بين الموظفين لتحقيق نوع من العدالة في عملية التوزيع لتحقيق الرضا للموظفين.

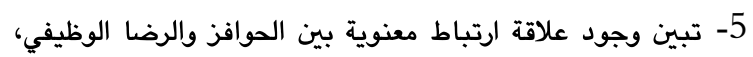
لذلك يوصي الباحثون بضرورة تعزيز نظام الحوافز بهدف تحقيق الرضا الوظيفي للموظفين في الجامعة. 6- تبين وجود تأثير معنوي للحوافز في تحقيق الرضا الوظيفي، لذلك يوصي الباحثون بضروة تبني الجامعة المبحوثة مخطط البحث الفرضي كآلية عمل للحوافز بهدف تمقيق الرضا الوظيفي للموظفين

ابو شرخ، نادر حامد عبد الرانق ، (2010 )، تقيىم أثر الحوافز على مستوى الادئ

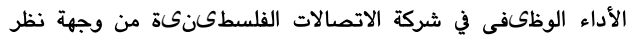
العاملىن، رسالة ماجستير، كلية الاقتصاد والعلوم الادارية، جامعة الادئ الأزهر ، غزة، فلسطين. الأغبري، عبدالصمد، (2002)، الرضا الوظيفي لدى عينة من مديري مدارس التعليم العام بالمنطقة الشرقية، دراسة ميدانية، مجلة دراسات الخليج والجزيرة العربية، مجلس النشر العلمي، جامعة الكويت.
الى زيادة مقداره (66.8\%) في الرضا عن مهام العمل وواجباته،ويدعم ذلك قيمة (F) المحسوية والبالغة (75.75)،وهي اكبر من قيمتها الجدولية والبالغة (4.042) ،كما أن مستوى المعنوية المحسوية والبالغة (0.008) كان أقل من مستوى المعنوية للبحث والبالغة (0.05) وضمن درجتي حرية (1-51) ، ويلفت القدرة التفسيرية للمتغير المستقل (الحوافز) في المتغير المعتمد (مهام العمل وواجباته)

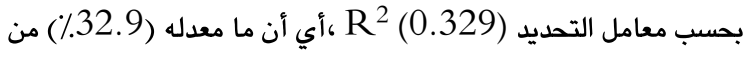
الاختلافات المفسرة في مهام العمل وواجباته تعود الى تاثير الحوافز، ويالمقابل فإن (67.1\%) من الاستجابة تعود لمتغيرات أخرى خارج

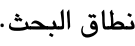

4- وجود تأثير معنوي موجب للحوافز مجتمعة في الرضا عن العلاقة مع الرؤساء والزملاء منفردة، وذلك من خلال قيمة الميل الحدي (B)

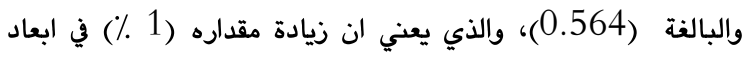

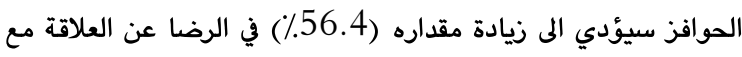
الرؤساء والزملاء ، ويدعم ذلك قيمة (F) المحسوية والبالغة

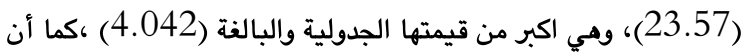

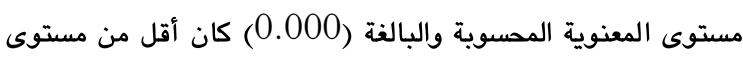

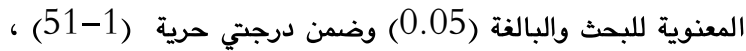
ويلفت القدرة التفسيرية للمتفير المستقل (الحوافز) في المتغير المعتمد (0.321) R R (العلاقة مع الرؤساء والزملاء) بحسب معامل التحديد)

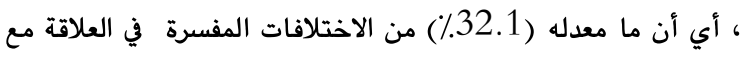

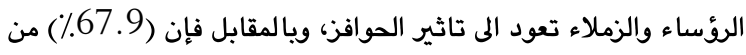
الاستجابة تعود لمتغيرات أخرى خارج نطاق البحث.

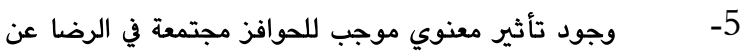

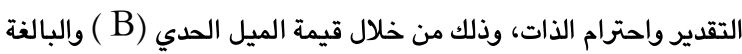
(0.560)، والذي يعني ان زيادة مقداره (1 \% ٪) في ابعاد الحوافز

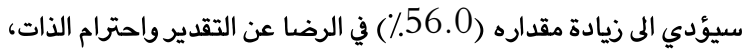
ويدعم ذلك قيمة (F) المحسوية والبالغة (23.38)، وهي اكبر من قيمتها الجدولية والبالغة (4.042)،كما أن مستوى المعنوية المحسوية والبالغة (0.000) كان أقل من مستوى المعنوية للبحث والبالغة (0.05) وضمن درجتي حرية (1-51) ، ويلغت القدرة التفسيرية للمتغير المستقل (الحوافز) في المتغير المعتمد (التقدير واحترام الذات)

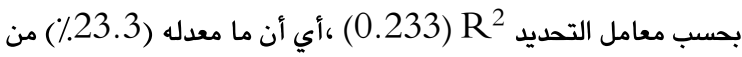
الاختلافات المفسرة في التقدير واحترام الذات تعود الى تاثير الحوافز، ويالمقابل فإن (76.7\%) من الاستجابة تعود لمتغيرات أخرى خارج

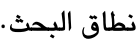

وعليه تشير المعطيات السابقة على تحقق الفرضية الرئيسة الثانية التي تنص على وجود تاثير معنوي للحوافز في أبعاد الرضا الوظيفي على المستوى الكلي والجزئي. 


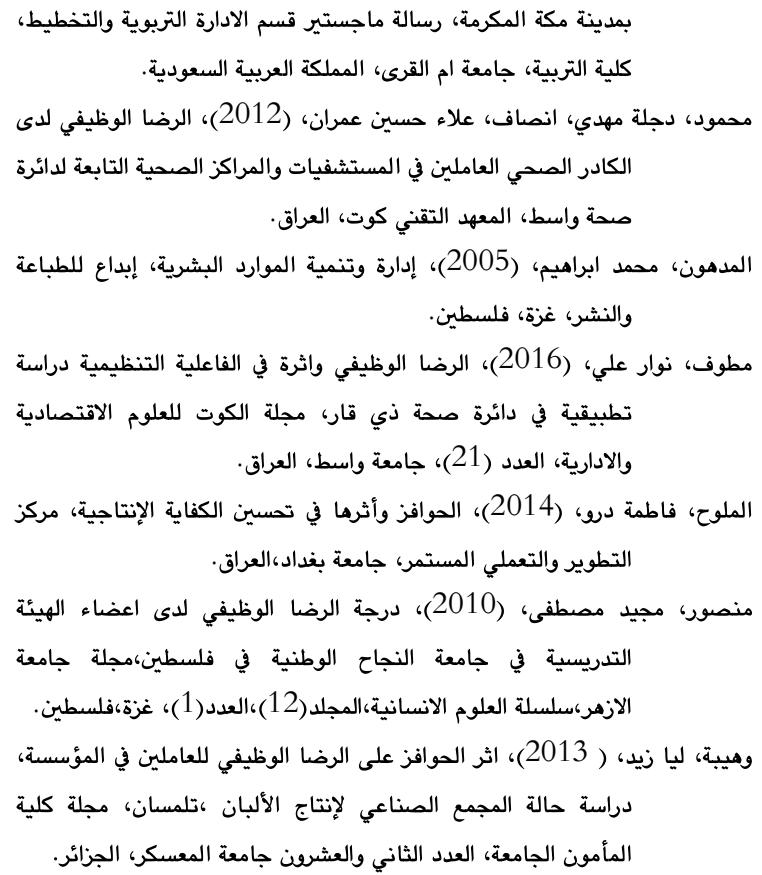

George and Jones (2006), Contemporary Management, McGRAW-HILL Inter.

Houldsworth Elizabeth and Jirasingle Dilum, (2006). " Managing and measuring Employee performance' . Kogan page Limited, London.

Kreitner, Robert, (2007), Management,10ed., McGrawHillCompanies Houghton Mifflin.

Lander, F., (2009), Multiple Impacts of Organizational Climate and Individual Value Systems Upon Job Satisfaction, Personnel Psychology Journal, 22,

Osa, Igbaekemem Goddy, (2014), Monetary Incentives Motivates Employee, s On Organizational Performance, Published by European Centre for Research Training and Development UK, Global Journal of Arts Humanities and Social Sciences, Vol.2, No.7.

Paul, Josiane de Saint, (2004), Estimede soi, confianceen soi, Paris, Inter Editions.

Robbins, Stephen and Judge, T., (2007), Organizational Behavior, Pearson Prentice Hall.

Stephen I. Dugguh, D,Ayaga, Dennis, Job Satisfaction Theories: Traceability to Employee Performance in Organizations,IOSR Journal of Business and Management, Volume 16, Issue 5. Ver. I May. 2014.

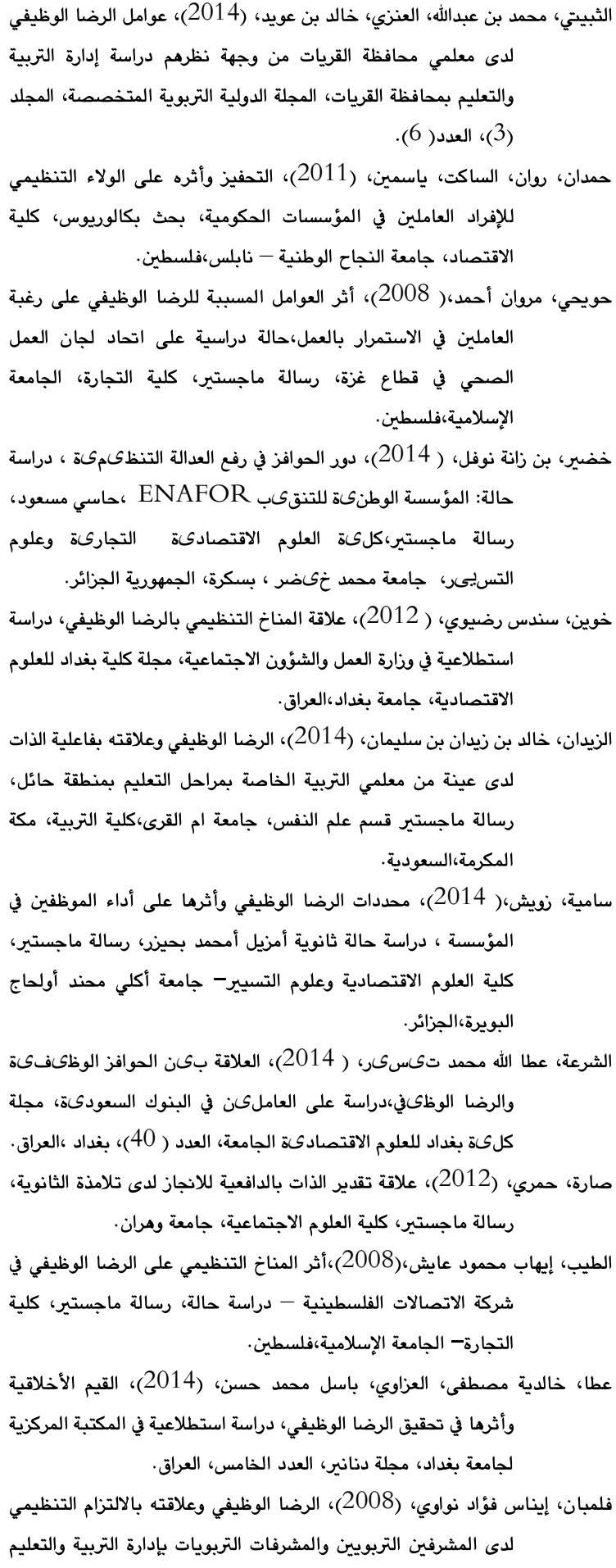




$$
\begin{aligned}
& \text { مع التقدير - معتم الباحت } \\
& \text { أولاً: المعلومات الشخصية ، رحية }
\end{aligned}
$$

يرجى التكرم بوضع إشارة ( X أمام العام العبارة التي تمثل الإجابة الصحيحية:

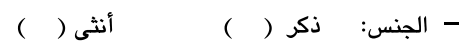

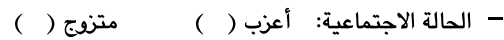

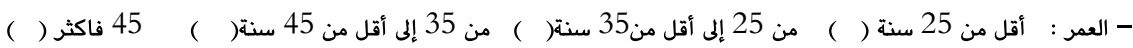
( ) 15 سنة فأكثر)

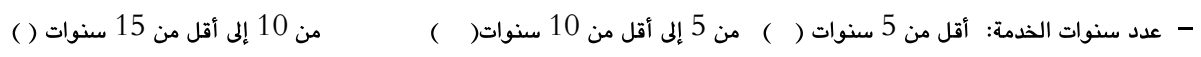
دراسات عليا ( )
بكالوريوس ( )

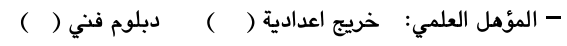

ثانياً: الحوافز

المحور الاول: الفقرات المتعلقة بالحوافز المادية والحوافز المعنوية )

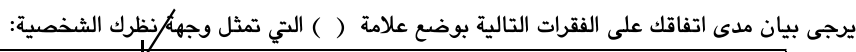

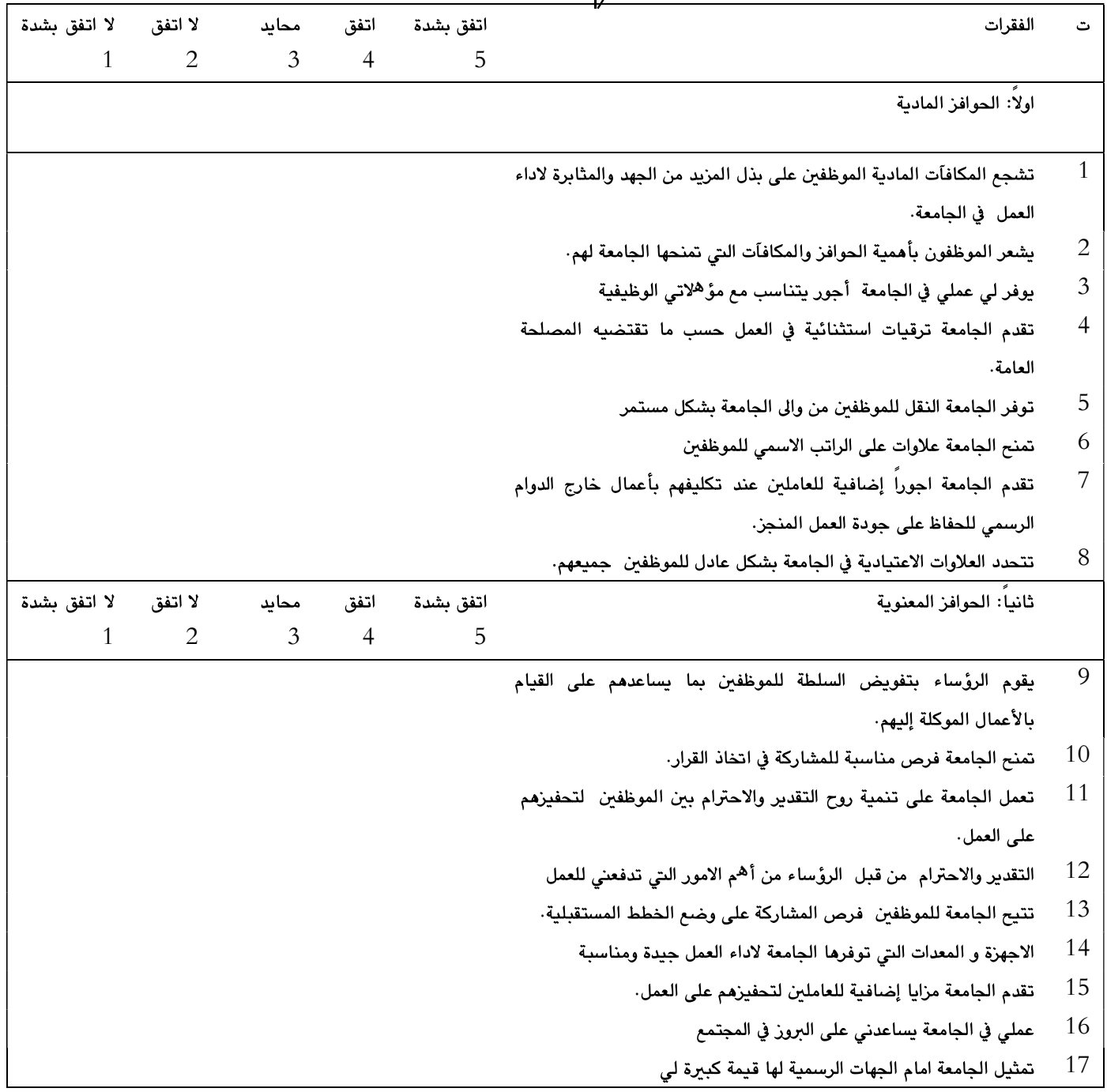




\begin{tabular}{|c|c|c|c|c|c|c|c|}
\hline \multirow{11}{*}{\multicolumn{2}{|c|}{$\begin{array}{r}1 \\
1 \\
\text { ل اتفق بشدة }\end{array}$}} & لا ل اتفق & محايد & اتفق & اتفق بشدة & 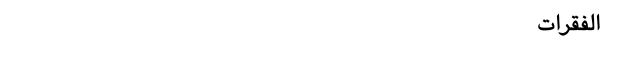 & $=$ \\
\hline & & 2 & 3 & 4 & 5 & & \\
\hline & & - & - & - & - & أولاً: الرضا عن الرواتب والأجور & \\
\hline & & & & & & الراتب الذي أحصل عليه يسد احتياجاتي & 18 \\
\hline & & & & & & أشعر الأجور المدفوعة تتناسب مع عبء العمل & 19 \\
\hline & & & & & & ان الراتب الحالي يكفي لسد متطلبات المعيشة الحالية & 20 \\
\hline & & & & & & يحقق الراتب الحالي الحد الأدنى من الرفاهية & 21 \\
\hline & & & & & & أشعر بان العمل والمهام الذي اقوم به يتناسب مع الراتب الذي أحصل & 22 \\
\hline & & & & & & 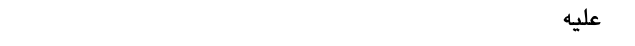 & \\
\hline & & & & & & يتناسب الراتب الذي احصل عليه مع الوضع الاقتصادي العام في & 23 \\
\hline & & & & & & 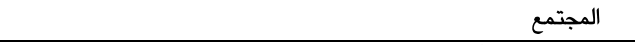 & \\
\hline & \multirow[t]{8}{*}{-} & - & - & - & - & ثانياً: الرضا عن المهام العمل وواجباته & \\
\hline & & & & & & يعقد المسؤول الاعلى اجتماعات خاصة من أجل مناقشات مادفة في & 24 \\
\hline & & & & & & 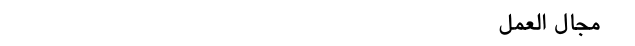 & \\
\hline & & & & & & المهام المطلوبة في العمل واضحة ودقيقة & 25 \\
\hline & & & & & & هناك صعويات تواجهني في عملي & 26 \\
\hline & & & & & & الوقت الذي يمنحه لي وظيفتي للتواجد مع أسرتي مناسب & 27 \\
\hline & & & & & & توجد عدالة في توزيع العمل بين الموظفين في القسم الواحد & 28 \\
\hline & & & & & & أكلف بأعمال تتناسب مع طبيعة اختصاصي & 29 \\
\hline & \multirow[t]{11}{*}{-} & - & - & - & - & ثالثاً : العلاقة مع الرؤساء والزملاء & \\
\hline & & & & & & هناك تفاهم بيني وبين رئيسي في الطريقة التي نتعامل بها & 30 \\
\hline & & & & & & يتعامل الرؤساء معنا باحترام وتقدير & 31 \\
\hline & & & & & & أشعر بعدالة الرؤساء في العمل. & 32 \\
\hline & & & & & & يهتم الرئيس بأرشاد الموظفين نحو العمل وسماع مقترحاتهم & 33 \\
\hline & & & & & & يعترف الرئيس بالجهد الذي أبذله في اداء عملي ويشجعني على الاداء & 34 \\
\hline & & & & & & 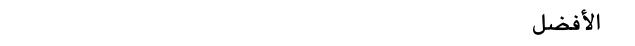 & \\
\hline & & & & & & تربطني علاقات حميمة مع زملائي في العمل & 35 \\
\hline & & & & & & يحرص الزملاء على تنمية الأنشطة الاجتماعية فيما بينهم. & 36 \\
\hline & & & & & & يحرص الزملاء على تبادل المعلومات ومصادر المعرفة فيما بينهم. & 37 \\
\hline & & & & & & يتبادل الزملاء مشاعر الود والاحترام . & 38 \\
\hline & \multirow[t]{6}{*}{-} & - & - & - & - & 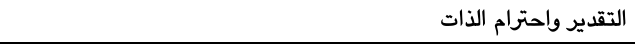 & رابعاً \\
\hline & & & & & & أشعر بالتقدير والاحترام من جميع الموظفين داخل الجامعة & 39 \\
\hline & & & & & & يكون العمل في الجامعة مصدر فخر وتقدير من قبل العائلة & 40 \\
\hline & & & & & & يمكن العمل في الجامعة الموظفين من الحصول على ما يستحقونه من & 41 \\
\hline & & & & & & تقدير & \\
\hline & & & & & & يوفر وظيفتي في الجامعة مركزا اجتماعيا جيدا يتناسب مع طموحاتي & 42 \\
\hline
\end{tabular}


روّلى دهرمالا د ريّكا بجه ئينانا رازيبونا فهرمانبهرايتيّ يه لدهف فهرمانبه ريّن زانكويا زاخو دا

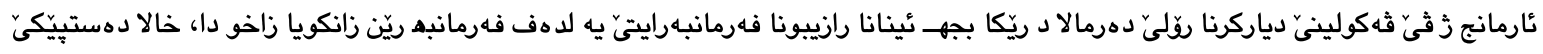

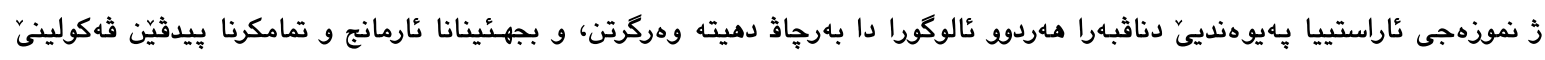

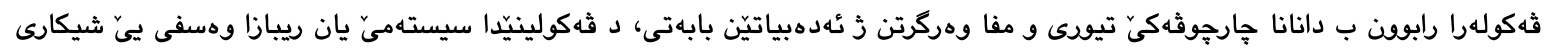

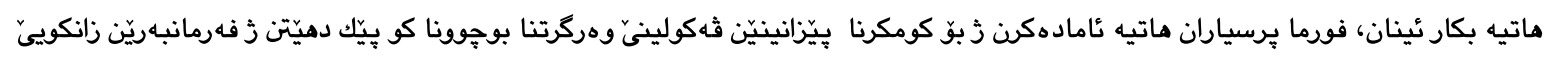

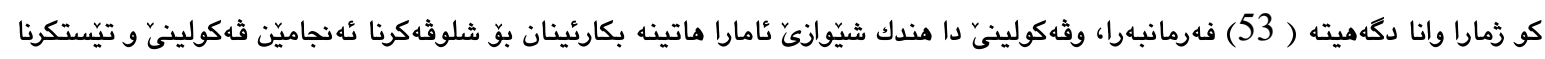
فهرهزياتا، ئهنجاميّن ييّن ثهكولينيّ دياركرن كو ناستيّن رازيبونا فهرمانبهرايتيّ يه ل زانكوييّ دا دميّته خاريّ دهريارى موجهه و كرييا دهيّته

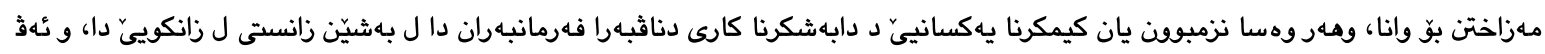

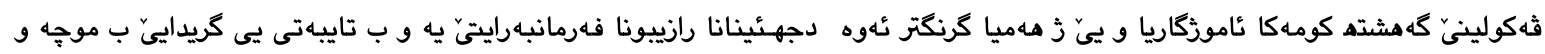

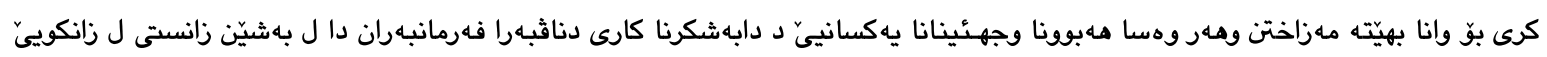

يَهيثيْن سهرهكى : دهرمالا، رازيبونا فهرمانبهرايتى يه، زانكويا زاخو.

\section{The role of incentives to achieve job satisfaction for staff at the University of Zakho "Exploratory Study"}

\section{Abstract:}

The starting point of the scheme supposedly takes into account the direction of the relationship between two variables, In order to achieve the goal of the research and complete the requirements of researchers began preparing a theoretical framework to benefit from the literature, And adopted in this research descriptive analytical method, questionnaire was used to solicit the views of the research sample, Consisting of staff who numbered (53) employees, some were used statistical methods to analyze the results and test hypotheses, The results of the study, The most important conclusions of the low satisfaction levels of staff at the University for salaries and wages granted to them, and as well as the weakness or the limited presence of justice at distribution work among staff in academic departments of the University, The research found a set of proposals represented the most important of the need to achieve satisfaction for employees, especially with regard to salaries and wages granted to them, As well as the achievement of justice at distribution work among staff in academic departments of the University.

Keywords: Incentives, Job Satisfaction, University of Zakho. 